\title{
Evaluation of natural fertilizer extracted from expired dairy products as a soil amendment
}

\author{
Mamdouh A. Eissa ${ }^{1 *}$, Nermeen N. Nasralla ${ }^{2}$, Nanis H. Gomah ${ }^{3}$, Dina M. Osman ${ }^{3}$, Yaser \\ M. El-Derwy ${ }^{3}$
}

${ }^{1}$ Department of Soils and Water, Faculty of Agriculture, Assiut University. Assiut 71526, Egypt. ${ }^{2}$ Dairy Sciences Department, Faculty of Agriculture (at New Valley), Assiut University, Assiut 71526, Egypt. ${ }^{3}$ Dairy Sciences Department, Faculty of Agriculture, Assiut University, Assiut 71526, Egypt. *Corresponding author: mamdouh.eisa@aun.edu.eg

\begin{abstract}
Dairy products contain high level of minerals and organic materials. The disposal of these materials is a source of environmental pollution and recourses loss. Recycling of expired dairy products is the ideal practical solution for an integrated ecosystem. Thus, a greenhouse trails were carried out to investigate the effectiveness of natural fertilizer extracted from expired dairy products. Expired dairy products powder (EDPP) was applied to wheat (Triticum aestivum vulgar) plants grown on pots filled with a sandy soil. The experiment contained three treatments: (C) control without any fertilization, (IF) inorganic fertilization (a mixture of inorganic fertilizers at a rate of $500 \mathrm{mg} \mathrm{N}+150 \mathrm{mg} \mathrm{P}+100 \mathrm{mg} \mathrm{K} /$ pot) and (EDPP) at a rate of $1 \%(10 \mathrm{~g} / \mathrm{pot})$. EDDP increased the degree of soil aggregation and water holding capacity by 24 and $38 \%$ in comparison to inorganic fertilization. The measured soil quality characteristics were improved as a result of the EDDP addition and this led to a remarkable improvement in wheat growth. EDPP elevated all the recoded growth parameters of wheat and increased the total chlorophyll by $22 \%$ in comparison to the IF treatment. The application of EDPP significantly raised N, P and K uptake by 45,73 and $95 \%$ compared to IF. EDPP minimized the $\mathrm{pH}$ of the soil by $10 \%$ and raised the availability of N, P and K by 54, 67 and 14 in comparison to the IF treatment. EDPP fertilizer caused a remarkable increase in wheat growth and improved soil properties. Based on the obtained results, the expired dairy products powder can be used as an organic fertilizer.
\end{abstract}

Keywords: Recycling, organic amendments, soil quality, expired dairy 


\section{Introduction}

Milk must have a very special interest in scientific studies because it is one of the most important human foods. The total world milk production was about 692 million tonnes in 2010 and may reach 827 million tonnes in 2020 (APPT, 2013). The global distribution of the world milk production in 2010 was as follow: South America 6.1\%, Asia Pacific $10.6 \%$, Eastern Europe 13.0\%, North America 15.3\%, India 16.3\%, Western Europe $21.3 \%$ and Rest of the world 17.4\% (APPT, 2013). Developing countries give one-third of the world milk production (Al-Rohily, 2010). Egypt accounted for $16.4 \%$ of Africa and Middle East dairy market in 2010 (APPT, 2013). The importance of dairy industry in Egypt comes from that it represents about $47 \%$ of the total companies engaged in agriculture and food industries (RAC/CP, 2002). Egypt produces 32.3 million tonnes of fresh milk yearly and this product is the major dairy product followed by cheese (FAOSTAT, 2015 and RAC/CP, 2002). Egyptian dairy factories give 4.1 and 2.8 million tonnes of cheese and yogurt yearly (RAC/CP, 2002).

Milk is rich with food compounds needed by the human body and contains $12.87 \%$ total solids, $4.28 \%$ fat, $8.59 \%$ solid not fat, $3.43 \%$ protein, $0.74 \%$ ash and $4.43 \%$ lactose (Teshome, 2015). Nitrogen in milk is also found in two forms, namely protein $(3.5 \%)$ and non-protein nitrogen (3-8\%) (Ribadeau and Grappin, 1989; Teshome, 2015). The concentrations of $\mathrm{Ca}, \mathrm{P}, \mathrm{Mg}, \mathrm{K}, \mathrm{Na}$ and $\mathrm{Cl}$ are 107-133, 63-102, 109-160, 144-178, 40-58, 90-106 mg/100g respectively, and the concentrations of $\mathrm{S}, \mathrm{Fe}, \mathrm{Cu}, \mathrm{Mn}$ and $\mathrm{Zn}$ are 32, 30-70, 2-30, 1.3-4.0 and 74-145 $\mu \mathrm{g} / 100 \mathrm{~g}$, respectively (Simun, 2012).

The safety of food is everybody's concern and the disposal of expired food products is one of the most important principles that must be taken into account to preserve human health (WHO, 2015). Disposal of expired products are one of the most important problem face the dairy industry. Expired dairy products e. g., milk, cheese and yoghurt must be returned to factories and must be disposed off as soon as possible when the expiration period expires (Dansted, 2016). There are different disposal methods for dairy products e. g., application to agriculture land, solidification and disposal at a permitted municipal solid waste landfill, haul to a permitted wastewater treatment stations and discharge to a permitted sanitary sewer (IDEM, 2002). The dairy products contain high amount of organic compound and elements which may be useful for plant nutrition (Teshome, 2015 and Simun, 2012) and the disposal of these materials in these ways is a major economic loss and non-recycling of these wastes threatens environmental disasters. The high levels of organic matter and nutrients encourage the recycling of wastes to be used for organic fertilization of agricultural lands (Adriano et al., 2012; Chrysargyris and Tzortzakis, 2015). The application of organic fertilizers to the soils improves the quality and availability of plant nutrients and increased the yield and economic returns (Scotti et al., 2015; Eissa, 2017). The organic fertilization is an effective tool in agriculture management and a low-price way to improve soil quality (Scotti et al., 2015).

The present research introduces a new way to recycling the expired dairy products as an organic fertilizer. Moreover, the study aims to evaluate the newly discovered fertilizer as an organic soil amendment.

\section{Materials and Methods}

\subsection{Preparation of organic fertilizer from expired dairy products powder (EDPP)}

Three types of expired dairy products were chosen for this study i.e., milk, yogurt, and cheese. Low fat 
protein powder was extracted and prepared for fertilization of wheat plants in a pot experiment. Expired liquid milk was separated using centrifugal separators (Alfa-laval 104, made in Sweden, $16000 \mathrm{Rpm}$ ) for one minute and then skimmed milk was collected and placed in open petri dishes to be dried in ovens with $60{ }^{\circ} \mathrm{C}$ and then dried milk was ground. Low fat protein was extracted from expired yoghurt by using gravity separation method after dilution with hot distilled water $\left(80^{\circ} \mathrm{C}\right)$ at a ratio of 1:3 (yoghourt: hot distilled water). Distilled water and yoghurt were mixed well with a blender and then the mixture was covered and left on bench for 8 hours without stirring. Three different layers were observed i.e., fat, water, and protein respectively from the surface to the bottom. The fat layer was removed and protein was filtered using clean fine clothes to get rid of excess liquid, then it was distributed in petri dish and dried in hot oven at $60{ }^{\circ} \mathrm{C}$ for drying until it is completely dried (36 hours). Low fat protein was extracted from expired cheese by using the same method applied in yoghurt with a dilution ratio of 1:7 (cheese: hot distilled water $80^{\circ} \mathrm{C}$ ). Dried low fat protein collected from those different expired dairy products was mixed and grinded. In the current study, low fat protein was extracted from milk, yogurt, and cheese to be used in wheat fertilization due to its high nutrients contents especially, nitrogen. The other parts of the separation processes contain high levels of fat and were used in animal nutrition experiment.

\subsection{Pot experiment}

This trail was conducted to evaluate the low fat protein powder as an organic fertilizer. The pot experiment contained three treatments i. e., i) control without any fertilization, ii) inorganic fertilization (a mixture of inorganic fertilizers at a rate of $500 \mathrm{mg} \mathrm{N}+150 \mathrm{mg}$ $\mathrm{P}+100 \mathrm{mg} \mathrm{K} /$ pot), and iii) expired dairy products powder (1\% equal to $10 \mathrm{~g}$ EDDP/pot). The amount of nitrogen, phosphorus and potassium in the inorganic fertilization and EDPP treatment was equal. Each treatment was mixed with the soil before cultivation. Commercial inorganic fertilizers of urea $(46 \% \mathrm{~N})$, super phosphate $\left(15.5 \% \mathrm{P}_{2} \mathrm{O}_{5}\right)$ and potassium sulphate $\left(48 \% \mathrm{~K}_{2} \mathrm{O}\right)$ were used in the second treatment.

The sandy soil used for the greenhouse trail was brought from the surface layer $(0-20 \mathrm{~cm})$ of El-Ghorieb soil which belongs to the farm of Assiut University, Egypt. The data in Table 1 show some physical and chemical characteristics of the experimental site. The collected soil sample was spread in the greenhouse to air-dry and then ground and sieved by a 2-mm sieve and blended by hands before located in one kg plastic pots. Five sides of wheat (Triticum aestivum vulgar, c.v. Solala 6) were placed in every pot and after two weeks, plants were thinned to three plants. Pots were irrigated to near filed capacity. Plant height and number of tillers were recorded after $60 \mathrm{~d}$ of planting then plants were removed and fresh and dry weights were recorded. The dried plant samples were kept for the determination of nitrogen, phosphorus and potassium. Soil samples were taken from each treatment to determine some soil physiochemical properties.

Table 1. Some chemical and physical properties of the studied soil.

\begin{tabular}{ll}
\hline Soil properties & Value \\
\hline Clay $\left(\mathrm{g} \mathrm{kg}^{-1}\right)$ & 50 \\
Silt $\left(\mathrm{g} \mathrm{kg}^{-1}\right)$ & 50 \\
Sand $\left(\mathrm{g} \mathrm{kg}^{-1}\right)$ & 900 \\
Texture & Sandy \\
Water holding capacity (\%) & 12 \\
Degree of soil aggregation $(\%)$ & 38 \\
Bulk density $(\mathrm{g} / \mathrm{cm})$ & 1.80 \\
Porosity $(\%)$ & 32 \\
CaCO $\left(\mathrm{g} \mathrm{kg}^{-1}\right)$ & 12 \\
$\mathrm{CEC}\left(\mathrm{cmol} \mathrm{kg}^{-1}\right)$ & 15 \\
pH $(1: 2)$ & 8.05 \\
EC $(1: 1)\left(\mathrm{dS} \mathrm{m}^{-1}\right)$ & 2.5 \\
Organic carbon $\left(\mathrm{g} \mathrm{kg}^{-1}\right)$ & 4.0 \\
Total nitrogen $\left(\mathrm{mg} \mathrm{kg}^{-1}\right)$ & 120 \\
Available nitrogen $\left(\mathrm{mg} \mathrm{kg}^{-1}\right)$ & 20 \\
Available Olsen P $\left(\mathrm{mg} \mathrm{kg}^{-1}\right)$ & 3.35 \\
Available-K $\left(\mathrm{mg} \mathrm{kg}^{-1}\right)$ & 100 \\
\hline Each value is the mean of three replicates
\end{tabular}

Each value is the mean of three replicates 


\subsection{Soil analysis}

Some physiochemical properties of the studied soil were determined according to Page et al. (1982). Analysis of soil (texture, total carbonate, cation exchange capacity (CEC), salinity, $\mathrm{pH}$, soil organic matter (SOM), total nitrogen, and available phosphorus and potassium) were determined by standard methods (Page et al., 1982). The $\mathrm{pH}$ of the soil samples was measured in 1:2 soil to water suspension using a digital pH meter (pH meter Model 211, Hanna Instruments, Romania). Salinity of soil was determined by EC-meter method (Page et al., 1982). Available soil nitrogen was extracted by $2 \mathrm{M} \mathrm{KCl}$.

Available and total $\mathrm{N}$ were measured by kjeldahl method (Page et al., 1982). Available P was extracted by $\mathrm{NaHCO}_{3}(0.5 \mathrm{M}$ and at $\mathrm{pH} 8.5)$ and phosphorus was determined by spectrophotometer (Page et al., 1982). Ammonium acetate (1 N) was used to extract the available soil $\mathrm{K}$ (Page et al., 1982). The degree of soil aggregation is defined as the percentage of clay inside the soil aggregates to the percentage of total clay in soil and was calculated from the difference between \%clay after dispersion and \%clay before dispersion dived by \%clay after dispersion (Lemmermann, 1934). Soil bulk density $\left(\mathrm{B}_{\mathrm{d}}\right)$ was measured by the ring method (Page et al., 1982) and was expressed as $\mathrm{g} / \mathrm{cm}^{3}$. Total soil porosity $(\% \mathrm{TP})$ was calculated from the equation: TP $(\%)=100 \times\left(1-\mathrm{B}_{\mathrm{d}} / \mathrm{P}_{\mathrm{d}}\right)$, where $B_{d}$ refers to bulk density $\left(\mathrm{g} / \mathrm{cm}^{3}\right)$ and $P_{d}$ refers to particle density $\left(2.65 \mathrm{~g} / \mathrm{cm}^{3}\right)$. Water holding capacity (WHC) was determined by the gravity flow method described by Haney and Haney (2010) and calculated by the equation:

$$
\% \text { WHC }=\frac{\text { (Wet weight }- \text { Oven dried weight })}{\text { Oven dried weight }} \times 100
$$

\subsection{Plant analysis}

The aboveground parts of wheat plant were cut from each pot and were used to study some growth parameters and uptake of $\mathrm{N}, \mathrm{P}$, and $\mathrm{K}$. All the collected samples were cleaned, washed with tap and distilled water, air dried, and then dried in oven at $70{ }^{\circ} \mathrm{C}$ until constant weight, ground and stored for chemical analysis. To determine the $\mathrm{N}, \mathrm{P}$, and $\mathrm{K}$ in plant uptake, 2.0 $\mathrm{g}$ of each sample were digested by $\mathrm{H}_{2} \mathrm{O}_{2}$ and $\mathrm{H}_{2} \mathrm{SO}_{4}$ method (Parkinson and Allen, 1975). Nitrogen, phosphorus and potassium in the digest was analyzed the above mentioned methods (Page et al., 1982). Chlorophyll content was measured in $80 \%$ acetone extract (Arnon, 1949).

\subsection{EDPP analysis}

The $\mathrm{pH}$ of EDPP was measured directly 1:2 powder to water suspension while the salt concentration was measured by EC-meter in the extract of powder and water at ratio of 1:5. Total organic carbon was measured by $1 \mathrm{~N} \mathrm{~K}_{2} \mathrm{Cr}_{2} \mathrm{O}_{7}$ (Page et al., 1982). To determine the total elemental composition $(\mathrm{N}, \mathrm{P}$, and $\mathrm{K})$, $2 \mathrm{~g}$ were digested by $\mathrm{H}_{2} \mathrm{O}_{2}$ and $\mathrm{H}_{2} \mathrm{SO}_{4}$ (Parkinson and Allen, 1975), then N, P and K content was measured by the above mentioned methods. The EDDP used in the current study has the following characteristics: $\mathrm{pH}$ $=4.85$, soluble salts $=3.70 \mathrm{dS} \mathrm{m}^{-1}, 450 \mathrm{~g}$ of organic carbon $\mathrm{kg}^{-1}, 50 \mathrm{~g} \mathrm{~N} \mathrm{~kg}^{-1}, 15.1 \mathrm{~g} \mathrm{P} \mathrm{kg}^{-1}$ and $10 \mathrm{~g} \mathrm{~K} \mathrm{~kg}^{-1}$.

\subsection{Data analysis}

The pot experiment contained three treatments and each one was replicated four times. The pot experiment was arranged in Complete Randomized Design (CRD). The one-way ANOVA was run by SPSS software (version 15) to test the statistically significant 
difference between the three treatments. Moreover, Duncan test (at 5\% probability) was performed to compare between means of the tested treatments.

\section{Results}

\subsection{Response of wheat growth to the different fertil-} ization treatments

Some wheat growth parameters were recorded during this pot experiment to evaluate the response of wheat to the inorganic fertilizers (IF) in comparison to the organic fertilizer extracted from the expired dairy products (EDPP) and the data are shown in Figures $1,2,3$ and 4. According to the recorded data of wheat growth (height of plants, tillers number, biomass yield, and chlorophyll content), EDPP caused a significant $(\mathrm{P}<0.05)$ increase in the growth of 60 days old wheat. The height of $60 \mathrm{~d}$-old wheat fertilized with EDPP was higher by $17 \%$ than that received the inorganic fertilization (Figure $1 \mathrm{~A}$ ). Number of tillers per pots as affected by the tested treatments is shown in
Figure 1-B. Fertilization of wheat plants by the EDPP enhanced the tillering rate by $60 \%$ compared to the inorganic fertilization. The biomass yield of wheat plants was also affected significantly $(\mathrm{P}<0.05)$ by the tested treatments. Fresh and dry weights of wheat plants shoot grown in the soil amended with $1 \%$ of EDPP were higher by 17 and $29 \%$ respectively, in comparison with that received the inorganic fertilization (Figure $2 \mathrm{~A}$ and $\mathrm{B}$ ). The root growth of wheat was significantly affected by the addition of $1 \%$ EDDP (Figure $3 \mathrm{~A}$ and B). The application of EDDP induced remarkable increases in the fresh and dry weights of roots. EDDP increased the FW and DW of wheat roots by 60 and $80 \%$ in comparison with the control and by 33 and $36 \%$ in comparison with the inorganic fertilization. The addition of $1 \%$ EDPP to soil raised the height of plants, tillers number and the biomass yield of wheat plants. Total chlorophyll was measured in the shoot tissue of 60d-old wheat and the data are shown in Figure 4. EDPP caused significant increases in the value of total chlorophyll; this increase was $27 \%$ in comparison to the control soil and $22 \%$ in comparison to the inorganic fertilization treatment.
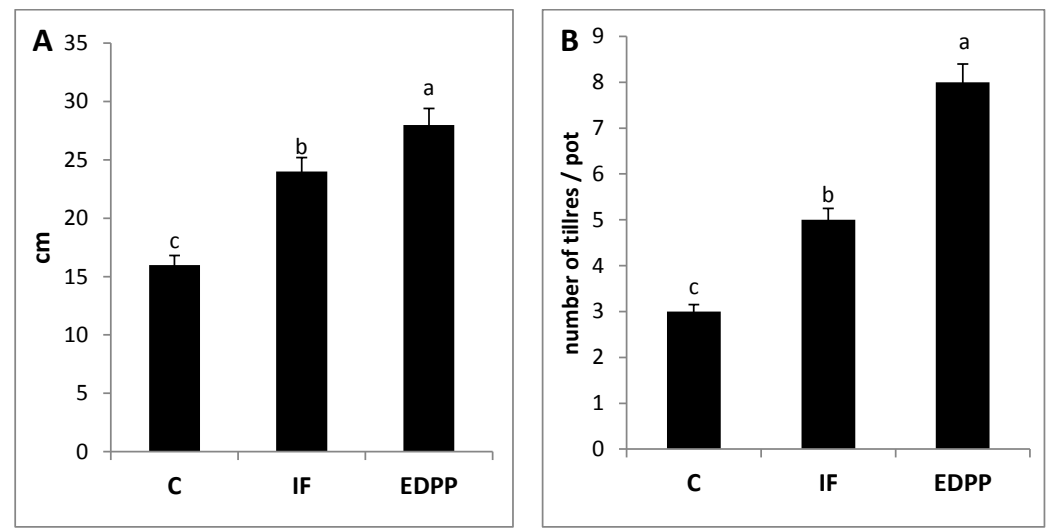

Figure 1.A) Plant height and B) number of tillers as affected by the different fertilization treatments $\mathrm{C}=$ control, $\mathrm{IF}=$ inorganic fertilization, $\mathrm{EDPP}=$ Expired dairy products powder. Means $( \pm \mathrm{SD}, \mathrm{n}=4)$ denoted by the same letter indicate no significant difference according to Duncan's test at $\mathrm{P}<0.05$ 

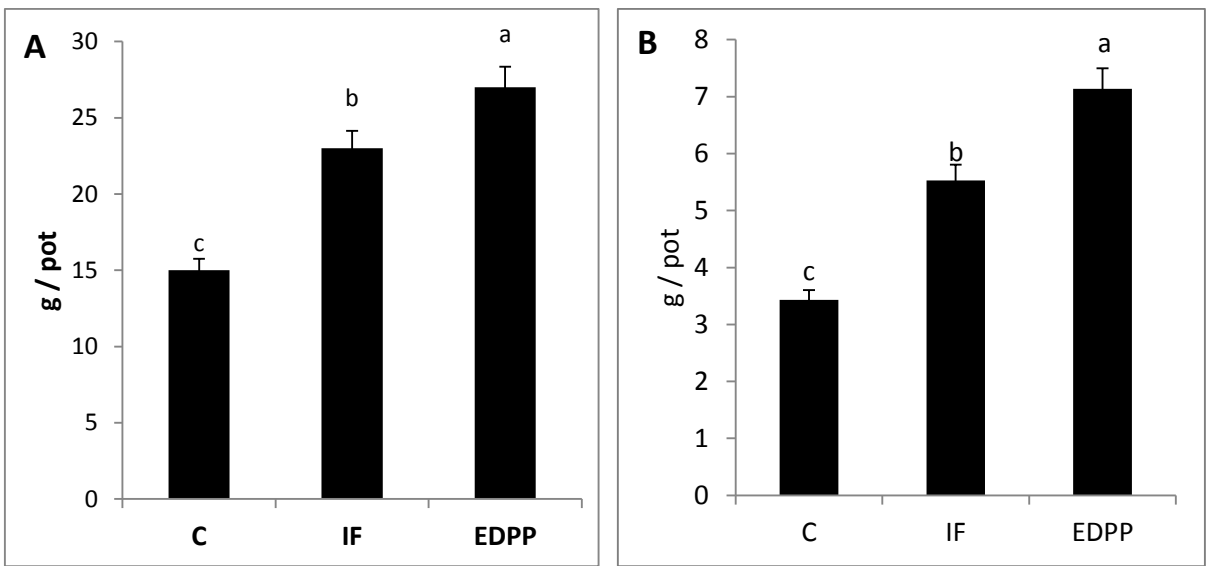

Figure 2. A) Fresh and B) dry weights of wheat shoots as affected by the different fertilization treatments $\mathrm{C}=$ control, $\mathrm{IF}=$ inorganic fertilization, $\mathrm{EDPP}=$ Expired dairy products powder. Means $( \pm \mathrm{SD}, \mathrm{n}=4)$ denoted by the same letter indicate no significant difference according to Duncan's test at $\mathrm{P}<0.05$
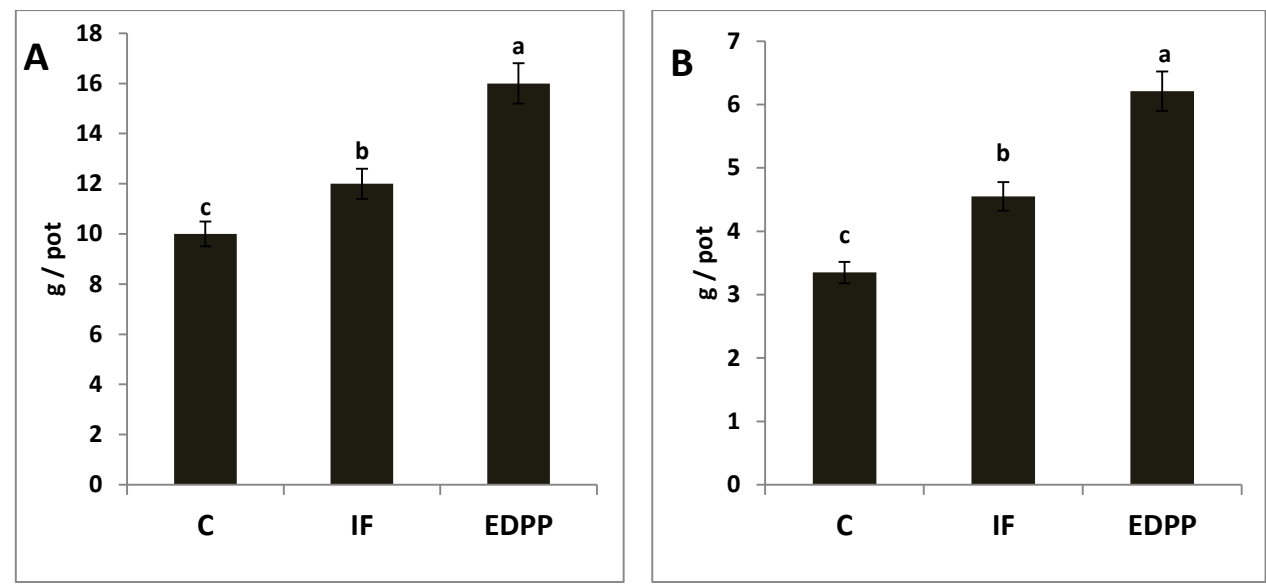

Figure 3. A) Fresh and B) dry weights of wheat roots

$\mathrm{C}=$ control, $\mathrm{IF}=$ inorganic fertilization, $\mathrm{EDPP}=$ Expired dairy products powder. Means $( \pm \mathrm{SD}, \mathrm{n}=4)$ denoted by the same letter indicate no significant difference according to Duncan's test at $\mathrm{P}<0.05$ 


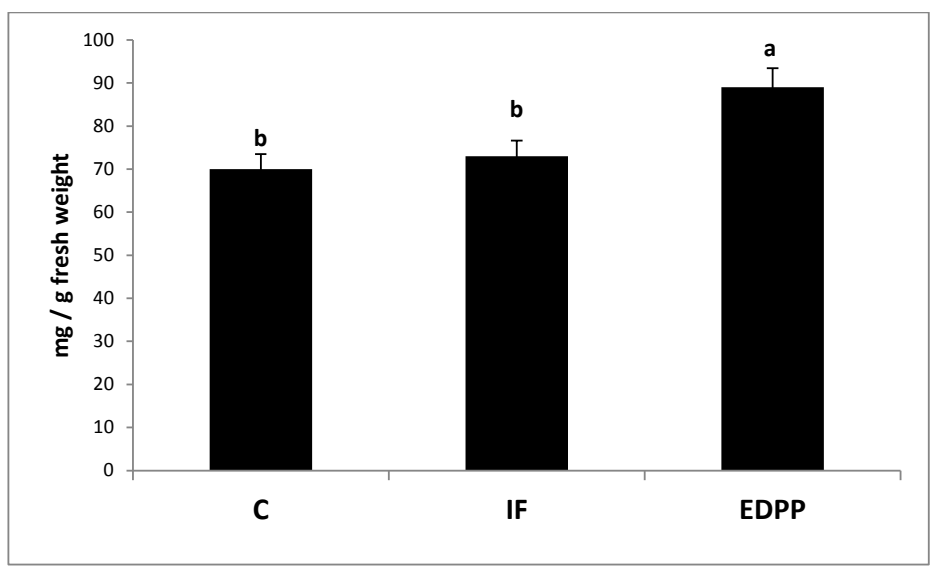

Figure 4. Total chlorophyll (mg / $\mathrm{g}$ fresh weights) as affected by the different fertilization treatments $\mathrm{C}=$ control, $\mathrm{IF}=$ inorganic fertilization, $\mathrm{EDPP}=$ Expired dairy products powder. Means $( \pm \mathrm{SD}, \mathrm{n}=4)$ denoted by the same letter indicate no significant difference according to Duncan's test at $\mathrm{P}<0.05$

\subsection{Impact of $E D D P$ and inorganic fertilization on nutrients availability and uptake by wheat plants}

Nitrogen, phosphorus and potassium uptake by $60 \mathrm{~d}-$ old wheat was evaluated to study the effect of EDPP and inorganic fertilization on nutrients uptake and the data are shown on Table 2. The application of EDPP significantly enhanced the uptake of $\mathrm{N}, \mathrm{P}$ and $\mathrm{K}$ and remarkable changes in the recorded data were found. The uptake of $\mathrm{N}, \mathrm{P}$ and $\mathrm{K}$ by wheat fertilized with EDPP raised by 45,73 and $95 \%$ compared with that fertilized with the inorganic fertilizers. EDPP applied to the studied soil raised the availability of N, P and $\mathrm{K}$ by 54,67 and $14 \%$ in comparison to that amended with the inorganic fertilizers.

Table 2. Nutrients availability and uptake by wheat plants

\begin{tabular}{|c|c|c|c|c|c|c|}
\hline \multirow[b]{2}{*}{ Treatments } & \multicolumn{3}{|c|}{ Nutrients availability $\left(\mathrm{mg} \mathrm{kg}^{-1}\right)$} & \multicolumn{3}{|c|}{ Nutrients Uptake $\left(\mathrm{mg} \mathrm{pot}^{-1}\right)$} \\
\hline & $\mathrm{N}$ & $\mathrm{P}$ & $\mathrm{K}$ & $\mathrm{N}$ & $\mathrm{P}$ & $\mathrm{K}$ \\
\hline $\mathrm{C}$ & $22 \mathrm{c}$ & $3.0 \mathrm{c}$ & $80 \mathrm{c}$ & $86 \mathrm{c}$ & $14 \mathrm{c}$ & $17 \mathrm{c}$ \\
\hline IF & $130 \mathrm{a}$ & $15 \mathrm{~b}$ & $120 \mathrm{~b}$ & $133 \mathrm{~b}$ & $33 \mathrm{~b}$ & $44 \mathrm{~b}$ \\
\hline EDPP & $200 \mathrm{~b}$ & $25 \mathrm{a}$ & $137 \mathrm{a}$ & $193 \mathrm{a}$ & $57 \mathrm{a}$ & $86 \mathrm{a}$ \\
\hline
\end{tabular}




\subsection{Impact of $E D D P$ and inorganic fertilization on some physiochemical characteristics of the studied soil}

The effects of EDDP on some physiochemical properties of the soil were studied to follow the changes in soil conditions and the data are shown in Table 3. The data show the effect of EDPP and inorganic fertilization on the $\mathrm{pH}$ of the soil, organic carbon (OC) and cation exchange capacity (CEC). EDPP application caused significant $(\mathrm{P}<0.05)$ effects on the soil $\mathrm{pH}$, $\mathrm{OC}$ and CEC. EDPP increased the OC and CEC by 56 and $33 \%$ compared to IF treatment. EDPP reduced the soil $\mathrm{pH}$ by $11 \%$ compared to IF. Remarkable changes were found in the recorded physical properties of the soil amended by EDDP. EDDP significantly decreased the soil bulk density by $23 \%$ in comparison with the soil fertilized by the inorganic fertilizers. Moreover, EDDP induced great significant increases in the water holding capacity (WHC), degree of soil aggregation (DSA) and total soil porosity (TSP). EDDP increased the WHC, TSP and DSA by 38, 47 and 30\% respectively, in comparison with control soil (Table 3).

Table 3. Some physiochemical characteristics of the soil after plant harvest

\begin{tabular}{ccccccccc}
\hline Treatments & $\mathrm{pH}$ & $\begin{array}{c}\mathrm{EC} \\
\mathrm{dS} \mathrm{m}^{-1}\end{array}$ & $\begin{array}{c}\mathrm{OC} \\
\mathrm{g} \mathrm{kg}^{-1}\end{array}$ & $\begin{array}{c}\mathrm{CEC} \\
\mathrm{cmol} \mathrm{kg}^{-1}\end{array}$ & $\begin{array}{c}\mathrm{B}_{\mathrm{d}} \\
\mathrm{g} \mathrm{cm}^{-1}\end{array}$ & $\%$ DSA & $\% \mathrm{TSP}$ & $\%$ WHC \\
\hline $\mathrm{C}$ & $7.89 \mathrm{a}$ & $2.0 \mathrm{c}$ & $5.2 \mathrm{~b}$ & $16.0 \mathrm{~b}$ & $1.70 \mathrm{a}$ & $40 \mathrm{~b}$ & $34 \mathrm{c}$ & $13 \mathrm{~b}$ \\
$\mathrm{IF}$ & $7.82 \mathrm{a}$ & $2.8 \mathrm{~b}$ & $5.5 \mathrm{~b}$ & $17.1 \mathrm{~b}$ & $1.70 \mathrm{a}$ & $42 \mathrm{~b}$ & $39 \mathrm{~b}$ & $13 \mathrm{~b}$ \\
EDPP & $7.04 \mathrm{~b}$ & $3.4 \mathrm{a}$ & $8.6 \mathrm{a}$ & $22.8 \mathrm{a}$ & $1.30 \mathrm{~b}$ & $52 \mathrm{a}$ & $50 \mathrm{a}$ & $18 \mathrm{a}$ \\
\hline
\end{tabular}

$\mathrm{C}=$ control, $\mathrm{IF}=$ inorganic fertilization, $\mathrm{EDPP}=$ Expired dairy products powder

$\mathrm{OC}=$ organic carbon, $\mathrm{CEC}=$ cation exchange capacity, $\mathrm{Bd}=$ bulk density, $\mathrm{DSA}=$ degree of soil aggregation,

$\mathrm{TSP}=$ total soil porosity and $\mathrm{WHC}=$ water holding capacity, Means denoted by the same letter indicate no significant difference according to Duncan's test at $\mathrm{P}<0.05$

\section{Discussion}

The current research paper aims to evaluate the effect of natural organic fertilizer which derived from expired dairy products on wheat cultivated on a sandy soil. The application of organic fertilizer derived from the expired dairy products increased the growth and nutrients uptake by wheat. Moreover, the examined fertilizer showed great effects on improvement of physiochemical characteristics of the studied soil. It is well known that the application of organic amendments increased the accumulation of dry matter and enhanced the plant growth (Akande et al., 2010; Olaniyi et al.
2010; Malik et al., 2013, Eissa, 2016; Amin and Essa, 2017). In the current study the application of EDDP increased all the recorded growth parameters i.e., plant height, number of tillers and biomass yield of wheat plants. Moreover, the application of EDDP induced a $22 \%$ increase in the total chlorophyll in leaves of wheat plants. Yield and photosynthetic characteristics of wheat were increased by organic fertilization (Jiang et al., 2004). The EDDP used in the current study contains a high level of organic carbon $\left(450 \mathrm{~g} \mathrm{~kg}^{-1}\right)$. Fertilization of plants by organic compounds may enhance the growth of plants by rising availability of nutrients e. g., nitrogen, phosphorous and potassium 
in soil (Eissa, 2016; Jiang et al., 2004) and by increasing the ability of soil to store water in available form (Baldock and Skjemstad, 1999; Zhang and Marschner, 2017). Great increase in available soil phosphorus was recorded by the study of Al-Rohily et al. (2013) as result of organic fertilization. This increase may be due to: the formation of complex between dissolving organic matter and phosphorus (Garg and Bahl, 2008), the release of $\mathrm{CO}_{2}$ during the decomposition of organic materials and the reaction of soil organic matter with soil $\mathrm{Ca}^{+2}$ which led to reduce $\mathrm{P}$ fixation (Tolanur and Badanur, 2003). The ability of plant to uptake nutrients is influenced by the root size and distribution (Wang et al., 2006). In the current study, the application of EDDP caused more than 33\% increase in root growth compared to the inorganic fertilization and this may explain the high increase in nutrients uptake by wheat. Eissa (2016) reported that organic fertilization of okra increased the root growth and nutrients uptake.

The application of EDDP enhanced the studied physiochemical characteristics of the soil. Each one kilogram of EDPP used in the current study contains 450 $\mathrm{g}$ of organic carbon and this may explain the increases in soil organic carbon by $56 \%$ and the soil cation exchange capacity by $33 \%$ in comparison to the inorganic fertilization. The cation exchange capacity (CEC) is one of the most important characteristics determine the behavior of organic material in soil (Murphy, 2014). CEC of organic compound ranged between 200 to $400 \mathrm{cmol} \mathrm{kg}^{-1}$ dry weight and this value is very higher than the CEC of some soil clay minerals e. g., kaolinite $\left(10 \mathrm{cmol}(+) \mathrm{kg}^{-1}\right)$ and smectite (25 -100 $\mathrm{cmol} \mathrm{kg}^{-1}$ ) (Moore, 1998). Sandy textures lands are always low in soil organic matter (SOM) and clay minerals and therefore have low cation exchange capacities (Murphy, 2014). Thus, the raising of SOM concentrations seriously enhances soil CEC, especially in the case for sandy texture (Mujiyati and Supriyadi, 2009). In the current study, SOM increased by $65 \%$ when the soil was amended by $1 \%$ of EDDP compared to the control soil. EDDP induced great increases in SOM which may lead to control soil water relationships characteristics, manage soil aeration, increase soil structure stability and raised the soil cation exchange capacity (Suryantini, 2002; Baldock and Skjemstad, 1999). The application of EDDP increased the degree of soil aggregate, total soil porosity and water holding capacity by 38,47 and $30 \%$ respectively, in comparison with control soil. The recorded increases in the data of soil quality well have positive effects on wheat plant growth (Suryantini, 2002; Baldock and Skjemstad, 1999). The growth as and leaf nitrogen N, $\mathrm{P}$, and $\mathrm{K}$ content increased with the application of organic amendments (Garg and Bahl, 2008; Al-Rohily et al., 2013; Eissa, 2016). Organic amendments are good sources for plant nutrition, provide soil microorganisms by energy and can induce great positive increases in soil quality (Suryantini, 2002).

\section{Conclusions}

Dairy products contain high level of plant nutrients and organic compounds. The disposal of these materials is a source of environmental pollution and recourses loss. The protein content part was gravitationally separated from expired dairy products and after oven drying it was used as a soil amendment. A greenhouse experiment was conducted out to investigate the effect of natural organic fertilizer which derived from expired dairy products on wheat cultivated on a sandy soil. The tested amendment caused great significant increases in the water holding capacity, degree of soil aggregation and total soil porosity. Moreover, it enhanced the availability and uptake of N, P and K. The remarkable improvement of soil quality induced an increase in wheat growth. Expired dairy products can be converted to an organic amendment and this is the ideal practical solution for an integrated ecosystem. 


\section{References}

Adriano, M. de L., Gutiérrez, F., Dendooven, L., Salvador-Figueroa, M. 2012. Influence of compost and liquid bioferment on the chemical and biological characteristics of soil cultivated with banana (Musa spp. L.). J. Soil Sci. Plant Nutr. 12 (1), 33-43.

Akande, M., Oluwatoyinbo, F., Makinde, E., Adepoju, A., Adepoju, I. 2010. Response of okra to organic and inorganic fertilization. Nat. Sci. 8 (11):261-266.

Amin, A. A., Eissa, M. A. 2017. Biochar effects on nitrogen and phosphorus use efficiencies of zucchini plants grown in a calcareous sandy soil. J. Soil Sci. Plant Nutr. 17, 912-921

Al-Rohily, K., Ghoneim, A., Modaihsh, A., Mahjoub, M. 2013. Phosphorus availability in calcareous soil amend with chemical phosphorus fertilizer, cattle manure compost and sludge manure. Int. J. Soil Sci. 8, 17-24. DOI: 10.3923/ijss.2013.17.24.

APPT (Association of Packaging and processing Technologies). 2013. Dairy Industry - A market assessment executive summary.

Arnon, D.I. 1949. Copper enzymes in isolated chloroplasts. Polyphenol oxidase in Beta vulgaris. Plant Physiol. 24, 1-15.

Baldock, J., Skjemstad, J. 1999. Soil organic carbon /Soil organic matter. In Peverill, K.I., Sparrow, L.A., Reuter, D.J. (eds). Soil Analysis - an interpretation manual. CSIRO Publishing Collingwood Australia.

Blasko, B. 2010. World importance and present tendencies of dairy sectors. Apstract. 5 (3-4), 119-123.

Chrysargyris, A., Tzortzakis, N. 2015. Municipal solid wastes and mineral fertilizer as an eggplant transplant medium. J. Soil Sci. Plant Nutr. 15, 11-23.
Dansted, P. 2016. Disposal of non-conforming dairy material or dairy product. https://www.mpi.govt. nz/document-vault/999.

Eissa, M.A. 2016. Phosphate and organic amendments for safe production of okra from metalcontaminated soils. Agron J. 108, 540-547.

Eissa M.A. 2017. Phytoextraction mechanism of $\mathrm{Cd}$ by Atriplex lentiformis using some mobilizing agents. Ecol. Eng. 108, 220-226.

FAOSTAT. 2015. Food and Agriculture Organization of the United Nations. http://faostat3.fao.org/ browse/Q/QA/E.

Garg, S., Bahl, G. 2008. Phosphorus availability to maize as influenced by organic manures and fertilizer P associated phosphatase activity in soils. Bioresour. Technol. 99, 5773-5777.

Haney, R.L.; Haney, E., Simple, B. 2010. Rapid laboratory method for rewetting dry soil for incubations. Commun. Soil Sci. Plan. 4, 1493-1501.

IDEM (Indian Department of Environmental Management). 2002. Proper disposal of dairy waste and cleanup requirements office of land quality. www. in.gov/idem/files/factsheet_cfo_dairy_disposal.pdf

Jiang, D., Dai, T., Jing, Q., Cao, W., Zhou, Q., Zhao, H., Fan, X. 2004. Effects of long-term fertilization on leaf photosynthetic characteristics and grain yield in winter wheat. Photosynthetica 42, 439-446.

Lemmermann, D. 1934. Methods for the investigation of soil. Verlag Chemie, Berlin, Germany.

Malik, M.A., Khan, K.S, Marschner, P. and Hassan, F. 2013. Microbial biomass, nutrient availability and nutrient uptake by wheat in two soils with organic amendments. J. Soil Sci. Plant Nutr. 13, 955-966.

Moore, G., Dolling, P., Porter, B., Leonard, L. 1998. Soil acidity. In Soil guide. A hand book for understanding and managing agricultural soils. (Ed. G Moore) Agriculture Western Australia Bulletin No. 4343. 
Mujiyati, I., Supriyadi, M. 2009. Effect of manure and NPK to increase soil bacterial population of Azotobacter and Azospirillus in chili (Capsicum annum) cultivation. Bioscience 1, 59-64.

Murphy, B.W. 2014. Soil Organic Matter and Soil Function - Review of the Literature and Underlying Data. Department of the Environment, Canberra, Australia.

Olaniyi, J.O., Akanbi, W.B., Olaniran, O.A., Ilupeju, O.T. 2010. The effect of organo-mineral and inorganic fertilizers on the growth, fruit yield, quality and chemical compositions of okra. J. of Anim. Plant Sci. 9, 1135-114.

Page, A.L., Miller, R.H., Keeney, D.R. 1982. Methods of Soil Analysis: Madison, Wisconsin, USA.

Parkinson, J.A., Allen, S.E. 1975. A wet oxidation procedure suitable for the determination of nitrogen and mineral nutrients in biological material. Commun. Soil Sci. Plan. 6, 1-11.

RAC/CP. 2002. Prevention of pollution in the dairy industry regional activity centre for cleaner production. Mediterranean Action Plan. Web page: http://www.cema-sa.org.

Ribadeau, B., Grappin, B. 1989. Milk protein analysis -Review. Elsevier/INRA Laft 69,357-416.

Scotti, R., Bonanomi, G., Scclza, R., Zoina, A. and Rao, M. A. 2015. Organic amendments as sustainable tool to recovery fertility in intensive agricultural systems. J. Soil Sci. Plant Nutr, 15, 333-352.
Suryantini, I. 2002. Utilization of organic materials and VAM for the growth and yield of peanut. In: Soejitno J, Herman, Sunihardi (ed). Environmentally friendly agricultural production systems. Center for Food Crop Research and Development. Agency for Agricultural Research and Development. Jakarta. [Indonesia].

Teshome, G., Fekadu, B. Mitiku, E. 2015. Physical and chemical quality of row cow's milk produced and marketed in Shashemene town, Southern Ethiopia. ISABB. J. Food and Agric. Sci. 5, 7-13.

Tolanur, S., Badanur, U. 2003. Effect of integrated use of organic manures, green manure and fertilizer nitrogen on sustaining productivity of rabi sorghum-chickpea system and fertility of a Vertisol. J. Indian Soc. Soil Sci. 51, 41-44.

Wang, H., Inukai, Y., Yamauchi, A. 2006. Root development and nutrient uptake. CRC Crit Rev Plant Sci. 25, 279-301.

WHO. 2015. Food Safety: What you should know http://www.searo.who.int/entity/world_health day/2015/whd-what-you-should-know/en/.

Zhang, Y., Marschner, P. 2017. Soil amendment with high and low $\mathrm{C} / \mathrm{N}$ residue -influence of low soil water content between first and second residue addition on soil respiration, microbial biomass and nutrient availability. J. Soil Sci. Plant Nutr. 17, 594-608 